\title{
Differential Impact of Land Use Types on Soil Productivity Components in Two Agro- ecological Zones of Southern Ghana
}

\author{
Folasade Mary Owoade, Samuel Godfried Kwasi Adiku, \\ Christopher John Atkinson, and Dilys Sefakor MacCarthy
}

\section{Contents}

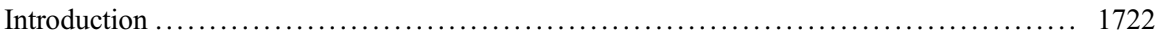

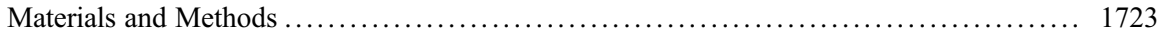

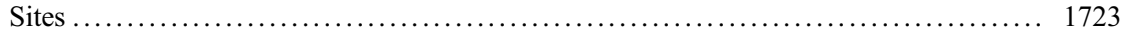

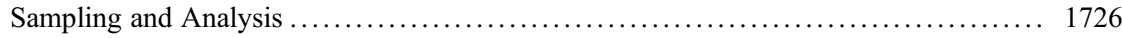

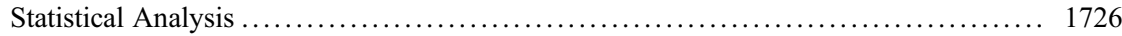

Results and Discussions ................................................. 1728

Effect of Site Locations on Soil Properties .................................. 1728

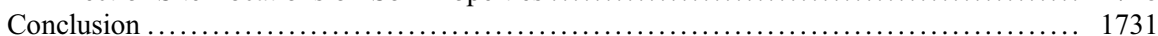

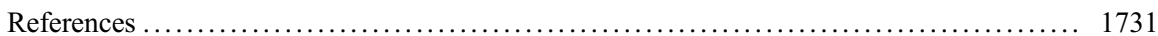

This chapter was previously published non-open access with exclusive rights reserved by the Publisher. It has been changed retrospectively to open access under a CC BY 4.0 license and the copyright holder is "The Author(s)". For further details, please see the license information at the end of the chapter.

F. M. Owoade $(\bowtie)$

Department of Crop Production and Soil Science, Ladoke Akintola University of Technology,

Ogbomoso, Nigeria

e-mail: fmowoade@lautech.edu.ng

S. G. K. Adiku

Department of Soil Science, University of Ghana, Legon, Ghana

e-mail: s_adiku@ug.edu.gh

\section{J. Atkinson}

Natural Resources Institute, University of Greenwich, London, UK

Department of Agriculture, Health and Environment, Natural Resources Institute, University of Greenwich, Chatham, UK

e-mail: C.J.Atkinson@greenwich.ac.uk

D. S. MacCarthy

Soil and Irrigation Research Centre Kpong, University of Ghana, Accra, Ghana

e-mail: dsmaccarthy@gmail.com 


\section{Abstract}

The maintenance of soil productivity is important for sustained crop yield in lowinput systems in the tropics. This study investigated the impact of four different land use types, namely, maize and cassava cropping, woodlot/plantations, and natural forests on soil productivity components, especially soil carbon accretion, at six sites within two agro-ecological zones of southern Ghana. Soil properties were significantly different between sites and ecological zones. The coastal savanna zones, which is a low rainfall zone had relatively lower soil carbon storage than the high rainfall forest-savanna transition zone. Soil productivity conditions in the later zone were much more favorable for cropping than the former. Land use types significantly affected the soil carbon (SOC) storage within the two ecological zones. In the low rainfall zone, soil carbon accretion by maize cropping, cassava cropping, and plantations were $48 \%, 54 \%$, and $60 \%$, respectively, of the forest carbon stock $(47,617 \mathrm{~kg} / \mathrm{ha})$. In the transition zone, the soil carbon accretion was over $90 \%$ of the forest value $(48,216 \mathrm{~kg} / \mathrm{ha})$ for all land use types. In effect use of land use types in maintaining soil productivity must consider the conditions in a given ecological zone.

\section{Keywords}

Agro-ecology $\cdot$ Land use $\cdot$ Soil carbon stock $\cdot$ Soil productivity $\cdot$ Soil properties

\section{Introduction}

Soil organic carbon $(S O C)$ is a major component of productivity in low-input cropping systems of the tropics. Soil carbon influences the physical, chemical, and biological properties of the soil. Many studies have indicated that the reduction in the $S O C$ can result in significant decrease in the available water capacity (Hudson 1994), structural deterioration, and an increased bulk density (Shu et al. 2015). Also, the contribution of the $S O C$ to soil fertility maintenance is also well established. Crop yield reduction is often associated with $S O C$ losses, largely because the $S O C$ is a major reservoir of nutrients, especially in the tropics where external inputs continue to remain low (Sanchez et al. 2009). Estimates by Lal (2006) indicated that maize yield could decline by $30-300 \mathrm{~kg} \mathrm{ha}^{-1}$ for every ton ha ${ }^{-1}$ of $S O C$ in the root zone. Regarding soil biology, the $S O C$ is a major source of nutrition and energy for microbial life. Some authors describe the $S O C$ as the "... life blood" of tropical soils (Acquaye 1989). Though the SOC plays a dominant role in tropical agriculture, other soil properties may also enhance the overall productivity. Nutrients elements such as nitrogen, which is largely derived from organic matter mineralization, phosphorus from rock minerals, and the overall cation retention capacity are important factors that also determine soil and crop productivity.

Soil carbon and hence productivity is not permanent but may change rapidly depending on land use type and management (Zerihun 2017; Waddington et al. 
2010; Reynolds et al. 2015). Much of the literature (Burras et al. 2001; Sa et al. 2001; Batlle-Aguilar et al. 2011) indicates that the conversion of forest to agriculture and other forms of land use such as plantations and woodlots is the major cause of soil productivity decline in the tropics. Brams (1971) showed a 50\% reduction in the SOC, only 5 years after forest clearing in Sierra Leone.

Residue management methods employed in agriculture also lead to changes in SOC. Adiku et al. (2009) showed in Ghana that where crop residues were removed (e. g., by burning, or cutting to feed animals with no return of manure), the $S O C$ declined rapidly from the long-term fallow land value of $18 \mathrm{~g} \mathrm{~kg}^{-1}$ to $7 \mathrm{~g} \mathrm{~kg}^{-1}$ with 4 years of maize cropping. However, where the residues were maintained as mulch, the rate of SOC decline was much slower, from $18 \mathrm{~g} \mathrm{~kg}^{-1}$ to $15 \mathrm{~g} \mathrm{~kg}^{-1}$ over years. A greater buildup of SOC in forests than other land use types would be expected because of long-term continuous litter addition (Brinson et al. 1980), for example, by avoidance of cultivation losses and reduced decomposition due to lower temperatures under a tree canopy. For croplands, the constant disturbance of the soil enhances SOC decomposition (Lal 1997; Hulugalle et al. 1984; Kang 1993; Dalal et al. 1991), and the constant harvest or removal of plant organic material (Feller 1993) would increase the SOC loss due to the partial exposure of the soil to high temperatures during off-seasons.

Despite these findings, the manner in which land use types affect soil carbon storage in different ecological zones is not well understood. The question of interest here is whether a given land use type will equally impact soil properties in different rainfall and vegetation zones. In other words, can we generalize that cropping will adversely affect soil productivity irrespective of the carbon input capacity of different ecological zones? This aspect of research is still lacking in Ghana, even though it has relevance for the design and management of soil productivity. The focus of this chapter is to examine how four land use types (forest, woodlot/plantation, cassava cropping, and maize cropping) affect soil carbon content and other properties at six farming sites of Ghana (across two ecological zones).

\section{Materials and Methods}

\section{Sites}

Six (6) farming sites from two agro-ecological zones, all in southern Ghana, were selected for this study (Fig. 1). Three of the farming sites (Accra Metropolis, Ga East District, Ga West District) fall in the coastal savanna zone of Ghana and receives 650-1000 mm rainfall. Though the vegetation is largely grassland, some derived savanna locations still host original pockets of forestland. The dominant soil type of the Greater Accra Region based on FAO/UNESCO classification is Ferric Acrisol and Umbic Leptosol (Soil Research Institute 1999). The remaining three sites (Yilo Krobo District, Shai Osudoku District, and Upper Manya District) fall within the forest-savanna transition zone (hereinafter transition zone) receiving 1500-2000 mm rainfall. Vegetation is largely forest at some portions and mixed with grassland in other portions. The soils of the transition comprise Cambic Arenosol and Calcic 


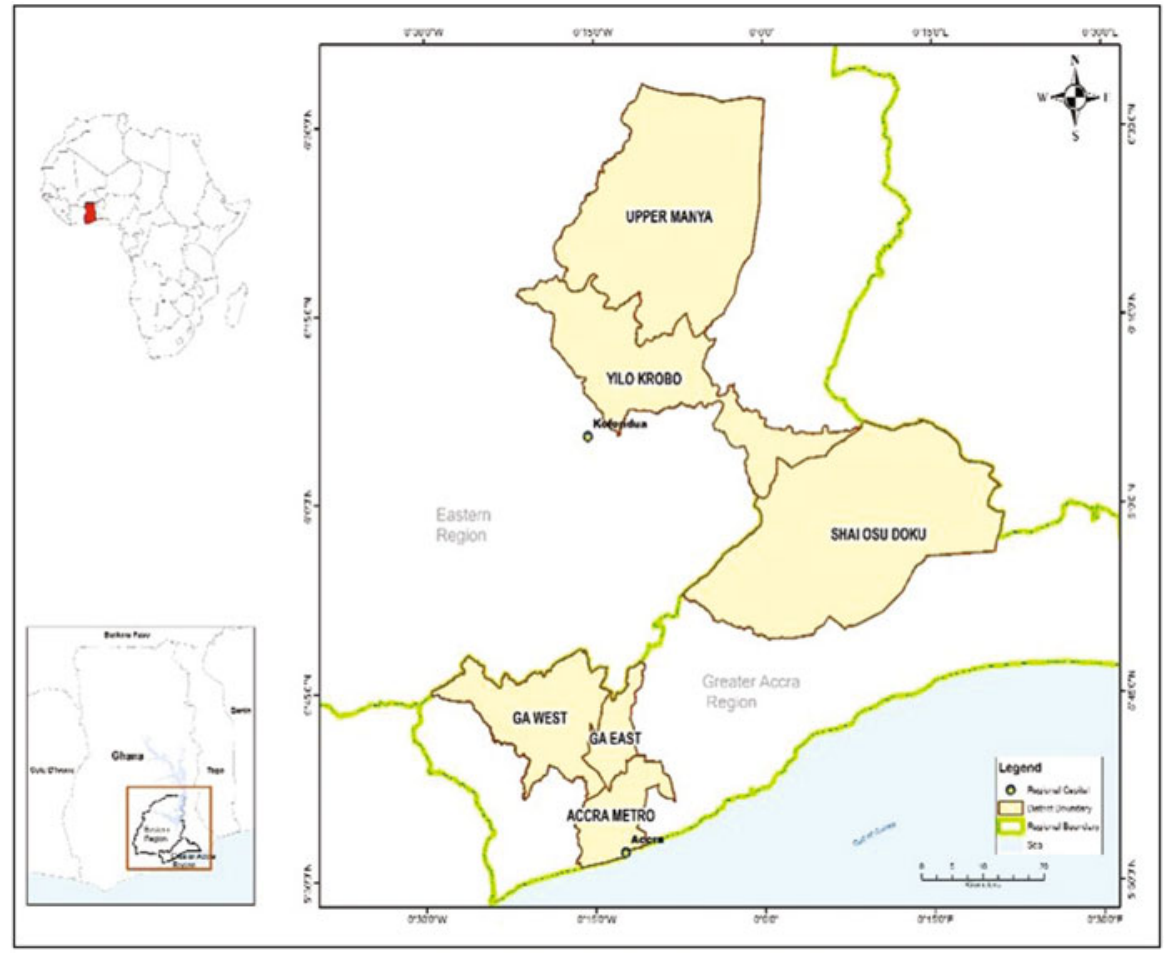

Fig. 1 Map shows position of Ghana in West Africa (top left), the location of the study sites in southern Ghana (bottom left), and the details of the districts (Ga West, Ga East, Accra Metropolis, Yilo Krobo, Shai Osudoku, and Upper Manya) used in Ghana

vertisol. Rainfall in both ecological zones is bimodally distributed, with a major wet season from March to July and a minor wet season from September to November. Agriculture is the main source of livelihood at all the sites.

The first site (Accra Metropolis) in the coastal savanna zone was located at the University of Ghana Farm and hosts a forest of more than 150 years old. Nearby the forest is cleared area which has been cropped to maize (Zea mays) and cassava (Manihot esculenta) for more than 20 years by University Farm workers. The maize fields receive periodically modest fertilizer application of not more than $30 \mathrm{~kg} \mathrm{~N} \mathrm{ha}^{-1}$. Also, located at the University Farm is an 18-year-old woodlot of Leucaena species established on a previously cropped land. Experimental plots at the University Farm were not included in this study. The soils under the forests and woodlots have little mechanical disturbance for many years, but the croplands are plowed and cultivated annually. The second site in this zone (Abokobi) also carried a 70-year-old forest with adjacent lands cropped to maize and cassava for not more than 10 years. A plantation of plantain (Musa spp.) was established near the forest. The third site (Pokuase) carried a forest of more than 70 years, an oil palm (Elaeis guineensis) plantation as well as cassava and maize farms. 
The fourth site (Yilo Krobo), which is located in the transition zone carried a forest of more than 50 years, an oil palm plantation and relatively young crop farms of maize and cassava. The fifth site (Shai Osudoku) holds a protected forest with mature trees of more than 100 years old. For this reason, soil sampling was restricted to the fringes of the forest. Other land use systems at this site include an 18-year mango (Mangifera indica) plantation, maize, and cassava farms. The sixth site (Upper Manya) has a forest of more than 50 years old, along with oil palm plantations, and recent arable farms.

Table 1 Land use types at the two agroecological zones

\begin{tabular}{|c|c|c|c|c|c|}
\hline Site & Ecology & \begin{tabular}{|l}
$\begin{array}{l}\text { Rainfall } \\
(\mathrm{mm})\end{array}$ \\
\end{tabular} & Dominant soil & Land use & $\begin{array}{l}\text { Age } \\
\text { (years) }\end{array}$ \\
\hline \multirow[t]{4}{*}{$\begin{array}{l}\text { Accra- } \\
\text { Metropolis }\end{array}$} & $\begin{array}{l}\text { Coastal } \\
\text { savannah }\end{array}$ & 700 & Ferric Acrisol & Maize & 10 \\
\hline & & & & Cassava & 10 \\
\hline & & & & Woodlot & 20 \\
\hline & & & & Forest & $>150$ \\
\hline \multirow[t]{4}{*}{ Ga-East } & $\begin{array}{l}\text { Coastal } \\
\text { savannah }\end{array}$ & 800 & Ferric Acrisol & Maize & 5 \\
\hline & & & & Cassava & 8 \\
\hline & & & & Plantation & 6 \\
\hline & & & & Forest & $>70$ \\
\hline \multirow[t]{4}{*}{ Ga-West } & $\begin{array}{l}\text { Coastal } \\
\text { savannah }\end{array}$ & 800 & $\begin{array}{l}\text { Umbic } \\
\text { Leptosol }\end{array}$ & Maize & 4 \\
\hline & & & & Cassava & 10 \\
\hline & & & & Plantation & 10 \\
\hline & & & & Forest & $>70$ \\
\hline \multirow[t]{4}{*}{ Yilo Krobo } & \begin{tabular}{|l|}
$\begin{array}{l}\text { Forest } \\
\text { savannah }\end{array}$ \\
\end{tabular} & $900-; 1500$ & Calcic Vertisol & Maize & 10 \\
\hline & & & & Cassava & 8 \\
\hline & & & & Plantation & 23 \\
\hline & & & & Forest & $>60$ \\
\hline \multirow[t]{4}{*}{ Shai-Osudoku } & \begin{tabular}{|l|}
$\begin{array}{l}\text { Forest } \\
\text { savannah }\end{array}$ \\
\end{tabular} & $900-1500$ & & Maize & $>50$ \\
\hline & & & & Cassava & $>50$ \\
\hline & & & & Plantation & 18 \\
\hline & & & & Forest & $>100$ \\
\hline \multirow[t]{4}{*}{ Upper-Manya } & \begin{tabular}{|l|}
$\begin{array}{l}\text { Forest } \\
\text { savannah }\end{array}$ \\
\end{tabular} & $900-1500$ & $\begin{array}{l}\text { Cambic } \\
\text { Arenosol }\end{array}$ & Maize & 5 \\
\hline & & & & Cassava & 7 \\
\hline & & & & Plantation & 10 \\
\hline & & & & Forest & $>50$ \\
\hline
\end{tabular}

Farmers' best estimates 


\section{Sampling and Analysis}

For this study, four land use types, namely, maize cropping, cassava cropping, plantations (teak, mango, plantain, oil palm, woodlot), and natural forests were selected (Table 1). Fifty-four (54) farms across the six sites were selected and visited from April to May 2017, and soils were sampled from each land use type from the depth of $0-20$. The cropping history of the 54 farms were documented during a prior survey by Owoade et al. (2017). At each site, at least three maize and three cassava farms were sampled in triplicates and bulked to obtain a composite sample for each farm. In addition, soils were sampled from the plantations and the natural forests.

The disturbed top soil $(0-20 \mathrm{~cm})$ and separately sampled undisturbed soil cores were brought to the laboratory for analysis. The bulk density was determined on the soil cores. Disturbed soils were air-dried, crushed, and sieved through 2-mm sieve for the determination of texture, total soil carbon, $\mathrm{pH}$, total nitrogen, available phosphorus, and exchangeable cations $(\mathrm{K}, \mathrm{Mg}, \mathrm{Ca}, \mathrm{Na})$. Exchangeable bases were determined by extraction with $250 \mathrm{ml}$ of buffered $1.0 \mathrm{M}$ ammonium acetate followed by flame photometric determination and the effective cation exchange capacity (ECEC) was determined as the sum of exchangeable cations. Soil texture determination followed the procedure of Bouyoucous (1951) as modified by Day (1965) using sodium hexametaphosphate as the dispersant. Soil $\mathrm{pH}$ was determined in 1:1 soil to water ratio using a MV88 Praitronic $\mathrm{pH}$ meter and electrode. Available phosphorus (AvP) was determined colorimetrically after extraction with Bray 1 solution (Bray and Kurtz 1945) and the concentration measured using a UV-Spectrophotometer. Total soil carbon and nitrogen were determined using TruMac Carbon, Nitrogen, and Sulfur analyzer (Model N1914).

The soil carbon content was converted to stocks $\left(C_{s t}\right)$ using:

$$
C_{s t}=A \times \rho_{b} \times z \times S O C
$$

where $A$ is the land area $\left(1 \mathrm{ha}=10^{4} \mathrm{~m}^{2}\right), \rho_{b}$ is the soil bulk density $\left(\mathrm{kg} / \mathrm{m}^{3}\right)$, and $z$ is the soil depth $(0.20 \mathrm{~m})$.

\section{Statistical Analysis}

Analysis of variance was conducted using MINITAB software to determine the influence of land use types and site location on soil properties. 


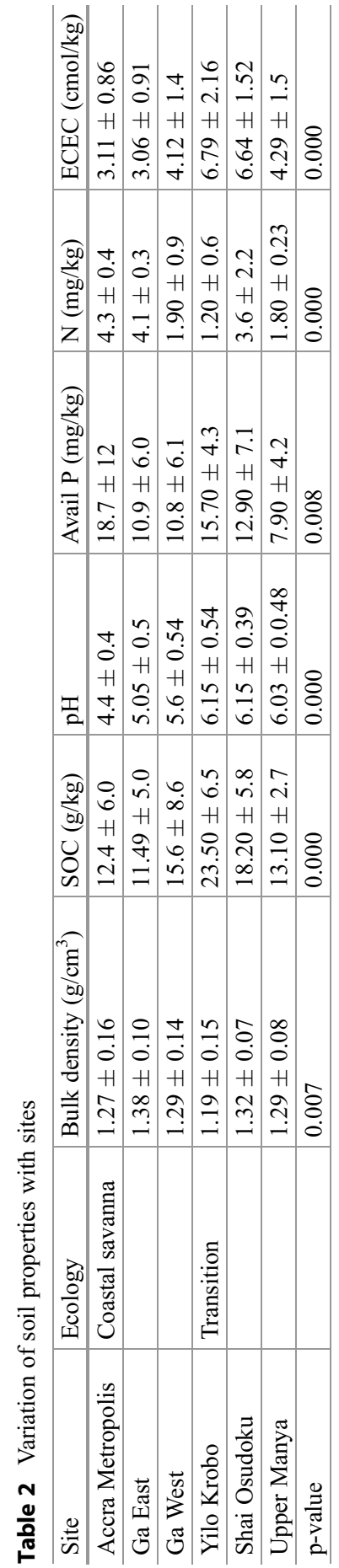




\section{Results and Discussions}

\section{Effect of Site Locations on Soil Properties}

There were significant differences among some soil properties at the various sites (Table 2). For example, soil texture, expressed as clay ratio (sand + silt)/clay), differed significantly with site, with high values $(>11)$ at sites $1,2,5$, and 6 , and low values (4-5) at locations 3 and 4 (not shown). The bulk density differed significantly with site $(p=0.007)$ with higher values observed for the coastal savanna zone $\left(1.3-1.4 \mathrm{~g} / \mathrm{cm}^{3}\right)$ than in the transition zone $\left(1.2-1.3 \mathrm{~g} / \mathrm{cm}^{3}\right)$. The $S O C$ also differed significantly with site $(\mathrm{p}=0.000)$, with higher values in the transition zone (1.3-2.4 g/ kg) than the coastal savanna zone (1.2-1.6 g/ kg). Apparently, the higher $S O C$ of the transition zone could be attributed to a greater carbon input by the high rainfall and more forest vegetation than the savanna ecological zone. The higher SOC of the transition zone may explain, the lower bulk density values, as these two properties are inversely related.

The $\mathrm{pH}$ differed significantly $(\mathrm{p}=0.000)$ between ecological zones with the transition zone having higher values (6.0-6.2) than the coastal savanna (4.4-5.6). Soil $\mathrm{pH}$ differences may have consequences to crop performance because most nutrient elements are usually available in the $\mathrm{pH}$ range of 5.5-6.5 (Motsara and Roy 2008). The available $\mathrm{P}$ was significantly different $(\mathrm{p}=0.008)$ among the sites. Though site 1 (Accra Metropolis) in the coastal savanna zone had the highest value $(18.7 \mathrm{mg} / \mathrm{kg})$, and the variability was also very high $(\mathrm{SD}=12 \mathrm{mg} / \mathrm{kg}$ ). Except for the site 6 (Upper Manya) which had the lowest available $\mathrm{P}(7.9 \mathrm{mg} / \mathrm{kg})$, the average $\mathrm{P}$ values were quite similar for the two ecological zones; $11-18 \mathrm{mg} / \mathrm{kg}$ for the coastal savanna and 8-16 $\mathrm{mg} / \mathrm{kg}$ for the transition zone. In general, the available P levels were somewhat adequate for plant growth, given a threshold of $11 \mathrm{mg} / \mathrm{kg}$ (Adeoye and Agboola 1985). Total nitrogen values varied significantly with site $(\mathrm{p}=0.000)$ with higher values for the coastal savanna (1.1$4.3 \mathrm{mg} / \mathrm{kg}$ ) than the transition zone $(1.2-3.6 \mathrm{mg} / \mathrm{kg})$. Though the ECEC can be considered as generally low but differed significantly $(p=0.000)$ between ecological zones, with the transition zone having 4.3-6.8 $\mathrm{cmol} / \mathrm{kg}$ and the coastal savanna having 3.1$4.1 \mathrm{cmol} / \mathrm{kg}$. Based on the soil property values, it may be concluded that the transition zone provided a much better soil condition for cropping than the coastal savanna zone.

Not all the soil properties were significantly affected by land use type. Across all sites, land use type had significant $(\mathrm{p}=0.003$ ) effect on the $S O C$, with a clear-cut difference between the $S O C$ of the forest $(21 \mathrm{~g} / \mathrm{kg})$ and the rest of the land use types where the $S O C$ ranged from 13.0 (maize) to 14.0 (woodlot/plantation) $\mathrm{g} / \mathrm{kg}$ (Table 3). Land use type also had significant effect $(p=0.000)$ on the bulk density, with the forests having the lowest value $\left(1.2 \mathrm{~g} / \mathrm{cm}^{3}\right)$ and maize farms having the highest $\left(1.34 \mathrm{~g} / \mathrm{cm}^{3}\right)$. There were no significant effects of land use types on available $\mathrm{P}, \mathrm{N}, \mathrm{ECEC}$, or $\mathrm{pH}$.

The interactive effects between sites and land use type were only significant for the $S O C$ and bulk density. Incidentally, these two properties are the major determinants of the total carbon stock (Eq. 1). Land use type significantly $(\mathrm{p}=0.013)$ affected the total carbon stocks at the various sites in the order: forest $>$ plantation $>$ cassava $>$ maize. Across the sites, the forest soils had the highest average storage of 48,216 $\pm 12,811 \mathrm{~kg} /$ 


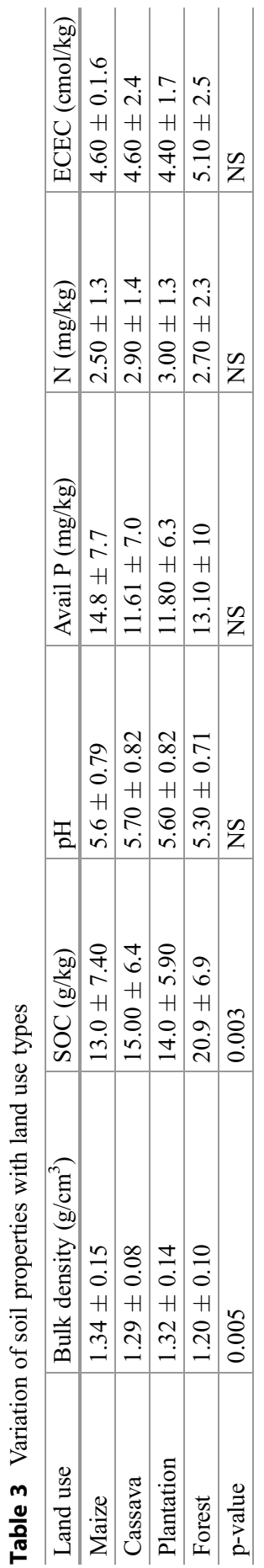


Table 4 Land use effects on soil carbon stocks

\begin{tabular}{l|l|r|l}
\hline Region & Land use & Carbon stock $(\mathrm{kg} / \mathrm{ha})$ & \% Forest carbon \\
\hline \multicolumn{2}{l}{ Coastal savanna } & \multicolumn{3}{l}{} \\
\hline & Maize & $24,316 \pm 12,155$ & 48 \\
\hline & Cassava & $27,671 \pm 10,839$ & 54 \\
\hline & Woodlot & $30,325 \pm 4450$ & 60 \\
\hline & Forest & $50,491 \pm 12,755$ & - \\
\hline Forest-savanna transition & & 88 \\
\hline & Maize & $41,897 \pm 12,263$ & 91 \\
\hline & Cassava & $43,001 \pm 10,007$ & 95 \\
\hline & Plantation & $45,019 \pm 14,786$ & - \\
\hline & Forest & $47,382 \pm 20,252$ &
\end{tabular}

ha "..(not shown) 4" followed by plantations $(36,774 \pm 14,482 \mathrm{~kg} / \mathrm{ha})$, cassava $(35,007 \pm 14,014 \mathrm{~kg} / \mathrm{ha})$, and maize $(33,905 \pm 12,811 \mathrm{~kg} / \mathrm{ha})$. Other studies (Djagbletey et al. 2018) have also reported higher soil carbon stocks for denser forests in the Guinean savanna zone of Ghana. In other works, carbon stocks as high as $59,450 \mathrm{~kg} / \mathrm{ha}$ determined for forest soils in the semi-deciduous forest zone of Ghana by Dawoe (2009).

With regard to ecological zones, the results showed that the differences in land use impact on soil carbon in the transition zone was smaller than in the coastal savanna zone (Table 4 ). In the coastal savanna zone, maize accrued $48 \%$ of the forest carbon stock, while the cassava and plantation accrued $54 \%$ and $60 \%$, respectively, suggesting that the plantations were most effective in soil carbon restoration. With regard to the transition zone, however, the soil carbon restoration effectiveness was generally high $90-95 \%$ for all the land use types. Though the plantations impact was again the highest, values above $90 \%$ accretion generally suggests that all the land use types were equally effective.

Options for $S O C$ accretion must consider the differential effects of land use types as well as ecological zones. Our observations indicated that cropping of the land depleted the $S O C$ the most. The reduction of SOC stocks on cropped lands can be attributed to factors such as the harvest removal of plant organic matter (Feller 1993), constant disturbance of the soil that enhances decomposition (Lal 1999; Hulugalle et al. 1984; Kang 1993; Dalal et al. 1991), and the partial exposure of soil to high temperatures during off-seasons when vegetation cover is reduced. These researchers (Yilfru and Taye 2011; Caravaca et al. 2002; Malo et al. 2005) also recorded greater SOC in forest compared to cultivated land. Though our sampling did not include intercropping systems, the observation that cassava cropping accrued high carbon stock than maize suggests that a maize-cassava intercropping could, perhaps, maintain a higher carbon addition, because of the longer life cycle of cassava and higher SOC accretion than maize.

The plantation land use type showed a higher SOC accretion but would require relatively long periods of time to achieve, thus preventing cropping of the lands for some time. Presumably, a combination of plantation and cropping is desired to ensure both crop productivity as well as $S O C$ maintenance. This can be accomplished by agroforestry, which has been promoted in many parts of the tropics to enhance crop 
yields (Kang 1993), but the adoption rates have continued to be very low. Apparently, the competition between live trees and crops for resources in agroforestry systems can reduce crop productivity (Ong et al. 1991), thereby handicapping the adoption of the system by farmers. Tree-crop rotations, as practiced under the traditional shifting cultivation, could also be an effective alternative to agroforestry. The tree phase of the rotation would permit the rebuild of the $S O C$ which is depleted during the cropping phase. This traditional shifting cultivation needs to be further researched for its role in soil carbon management and crop production.

\section{Conclusion}

Soil productivity in Ghana is influenced by both land use type and agro-ecological zone. Findings from this study indicated that soil productivity conditions for agriculture were less favorable for agriculture in the coaster savanna than the forestsavanna transition zone. Furthermore, land use types had significant impact on the carbon storage, with maize-based cropping systems having the lowest carbon stocks. Woodlot/plantation types of land use restored the SOC and productivity more effectively than croplands. In effect, the effectiveness of land use systems for soil productivity maintenance differs with agro-ecological zones. This must be factored into the design of land management measures.

Acknowledgment This research is supported by funding from the UK's Department for International Development (DfID) under the Climate Impacts Research Capacity and Leadership Enhancement (CIRCLE) program implemented by the African Academy of Sciences and the Association of Commonwealth Universities.

\section{References}

Acquaye DK (1989) Towards the development of sustainable agriculture in Africa. Reflections of a soil scientist. In: Proceedings of the 11th and 12th general meeting, Soil Science Society of Ghana. University of Ghana, Accra, $p 91$

Adeoye GO, Agboola AA (1985) Critical levels for soil $\mathrm{pH}$, available P, K, Zn and Mn and maize ear-leaf content of $\mathrm{P}, \mathrm{Cu}$ and $\mathrm{Mn}$ in sedimentary soils of South-Western Nigeria. Nutr Cycl Agroecosyst 6:65-71

Adiku SGK, Jones JW, Kumaga FK, Tonyiga A (2009) Effects of crop rotation and fallow residue management on maize growth, yield and soil carbon in a savanna- forest transition zone of Ghana. J Agric Sci 147(3):313-322

Batlle-Aguilar B, Porporato A, Barry D (2011) Modelling soil carbon and nitrogen cycles during land use change. A review. Agron Sustain Dev 31(2):251-274

Bouyoucous GH (1951) A calibration of the hydrometer for making mechanical analysis of soils. Agron J 43:434-438

Brams EA (1971) Continuous cultivation of West African soils: organic matter diminution and effects of applied lime and phosphorus. Plant Soil 35:401-414. https://doi.org/10.1007/ BF01372671

Bray RH, Kurtz LT (1945) Determination of total, organic, and available forms of phosphorus in soil. Soil Sci 59:39-45 
Brinson M, Bradshaw HD, Holmes RN, Elkins JB Jr (1980) Litterfall, stemflow and throughfall nutrient fluxes in an alluvial swamp forest. Ecology 61:827-835

Burras L, Kimble JM, Lal R, Mausbach MJ, Uehara G, Cheng HH, Kissel DE, Luxmoore RJ, Rice CW, Wilding LP (2001) Carbon sequestration: position of Soil Science Society of America. http://www.soils.org/carbseq.html

Caravaca F, Masciandaro G, Ceccanti B (2002) Land use in relation to soil chemical and biochemical properties in a semi-arid Mediterranean environment. Soil Tillage Res 69(1):23-30. https://doi.org/10.1016/s0167-1987(02)00080-6

Dalal RC, Strong WM, Weston EJ, Gaffney J (1991) Soil fertility decline and restoration of cropping lands in sub-tropical Queensland. Trop Grasslands 25:173-180

Dawoe E (2009) Conversion of natural forest to cocoa agroforest in Lowland Humid Ghana: impact on plant biomass production, organic carbon and nutrient dynamics. PhD thesis, Department of Agroforestry, Kwame Nkrumah University of Science and Technology, Kumasi, $260 \mathrm{pp}$

Day PR (1965) Particle fractionation and particle size analysis. In: Black CA et al (eds) Methods of soil analysis, Part I. Agronomy, vol 9. American Society of Agronomy, Madison, pp 545-567

de Sa JCM, Cerri CC, Dick WA, Lal R, Venske-Filho SP, Piccolo MC, Feigl BE (2001) Organic matter dynamics and carbon sequestration rates for a tillage chronosequence in a Brazilian Oxisol. Soil Sci Soc Am J 65:1486-1499

Djagbletey ED, Logah V, Ewusi-Mensah N, Tuffuour HO (2018) Carbon stocks in the Guinea savanna of Ghana: estimates from three protected areas. Biotropica 1-9. https://doi.org/10.1111/ btp.12529...org/10.5061/dryad.d1d30

Feller OE (1993) Organic input, soil organic matter and functional soil organic compartments in low-activity clay soils in tropical zones. In: Mulongoy K, Merckx R (eds) Soil organic matter dynamics and sustainability of tropical agriculture. Wiley, New York, pp 77-85

Hudson BD (1994) Soil organic matter and available water capacity. J Soil Water Conserv 49:189194

Hulugalle NR, Lal R, Ter Kuille CHH (1984) Soil physical changes and crop root growth following different methods of land clearing in Western Nigeria. Soil Sci 138:172-179

Kang BT (1993) Alley cropping: past achievements and future directions. Agrofor Syst 23(23):141-155. https://doi.org/10.1007/BF00704912

Lal R (1997) Soil degradative effects of slope and maize monoculture effects on a tropical Alfisols in Western Nigeria and soil physical properties. Land Degrad Dev 8:325-342

Lal R (1999) Soil management and restoration for C sequestration to mitigate the greenhouse effect. Prog Environ Sci 1:307-326

Lal R (2006) Enhancing crop yields in the developing countries through restoration of soil organic carbon pool in agricultural lands. Land Degrad Dev 17:197-209

Malo DD, Schumacher TE, Doolittle JJ (2005) Long term cultivation impacts on selected soil properties in the northern Great Plains. Soil Tillage Res 81:27-29

Motsara MR, Roy RN (2008) Guide to laboratory establishment for plant nutrient analysis, FAO fertilizer and plant nutrition bulletin 19. FAO, Rome

Ong CK, Corlett JE, Singh RP, Black CR (1991) Above and below ground interactions in agroforestry systems. For Ecol Manag 45:45-57

Owoade FM, Adiku SGK, Atkinson CJ, Kolawole GO, MacCarthy DS, Narh S (2017) Residue retention practices for carbon sequestration in some Ghanaian soils: a survey of willingness towards climate change mitigation. In: Proceedings of the international conference on climate change and sustainable development in Africa (ICCCSDA): climate change and sustainable development: strengthening Africa's adaptive capacity. University of Energy and Natural Resources, Sunyani, 25-28 July 2017

Reynolds TW, Waddington SR, Anderson CL, Chew A, True Z, Cullen A (2015) Environmental impacts and constraints associated with the production of major food crops in Sub-Saharan Africa and South Asia. Food Sec 7:795-822

Sanchez P, Denning G, Nziguheba G (2009) The African green revolution moves forward. Food Sec $1: 37-44$ 
Shu X, Zhu A, Zhang J, Yang W, Xin X, Zhang X (2015) Changes in soil organic carbon and aggregate stability after conversion to conservation tillage for seven years in the Hung-Huai-Hai Plain of China. J Integr Agric 14:1202-1211

Soil Research Institute (1999) Soil map of Ghana, FAO/UNESCO (1990). Land suitability section. Soil Research Institute, CSIR, Accra

Waddington SR, Li X, Dixon J, Hyman G, de Vicente MC (2010) Getting the focus right: production constraints for six major food crops in Asian and African farming systems. Food Sec 2:27-48

Yilfru A, Taye B (2011) Effects of land use on soil organic carbon and nitrogen in soil of Bale, South eastern Ethiopia. Trop Subtrop Agro Ecosyst 14(1):229-235

Zerihun T (2017) Raising crop productivity in Africa through intensification. Agronomy 7:22; 30 . https://doi.org/10.3390/agronomy7010022

Open Access This chapter is licensed under the terms of the Creative Commons Attribution 4.0 International License (http://creativecommons.org/licenses/by/4.0/), which permits use, sharing, adaptation, distribution and reproduction in any medium or format, as long as you give appropriate credit to the original author(s) and the source, provide a link to the Creative Commons license and indicate if changes were made.

The images or other third party material in this chapter are included in the chapter's Creative Commons license, unless indicated otherwise in a credit line to the material. If material is not included in the chapter's Creative Commons license and your intended use is not permitted by statutory regulation or exceeds the permitted use, you will need to obtain permission directly from the copyright holder.

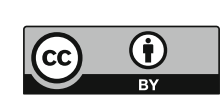

